Milena Z. Škobo

Sinergija University

Faculty of Philology in Bijeljina

Department of

English Language and Literature
УДК: $371.3:: 821.111]: 004.738 .5$

https://doi.org/10.18485/uzdanica.2020.17.2.2

Стручни рад

Примљен: 30. септембар 2020.

Прихваћен: 11. децембар 2020.

\title{
INNOVATIVE APPROACHES TO TEACHING (VICTORIAN) LITERATURE IN THE DIGITAL AGE
}

Abstract: The aim of this paper is to explore the most recent approaches to teaching Victorian literature at tertiary education. The paper deals with the challenges of teaching literature in the digital age and explores several unconventional ways of studying, teaching and interpreting traditional literary texts, in particular, the techniques and strategies employed at a course covering the literature of the Victorian period (English Literature II) conducted in winter semester during the academic year 2019/2020 at the Faculty of Philology at Sinergija University in Bijeljina, the Republic of Srpska. The teaching method introduced to the second-year students attending English Literature II involves setting up a forum discussion board via Wix Mobile Application, using the Actively Learn language platform, creating a Facebook page of a chosen literary character, and making online quizzes and games on Sporcle - World's Largest Trivia Website Quiz. The online tools and social media are used along with online games and quizzes, communicative language teaching activities and modern language-based activities that employ the four main language skills, activate the students' prior knowledge and engage students in meaningful communication triggered by the general understanding of the literary texts and the parallels that can be drawn between the $19^{\text {th }}$ and $21^{\text {st }}$ centuries from the perspective of the digital-native students. The paper opens further questions in regard to the application of modern technology and the most recent online tools to teaching literature and calls for a necessity to further research the methodology of teaching literature in the digital context.

Keywords: digital age, literature teaching, unconventional approaches, online tools.

\section{INTRODUCTION}

Nowadays teaching and reading literature at secondary and tertiary education is about to cease to be attractive to the $21^{\text {st }}$-century students enrolled in the courses conducted at departments of foreign languages as a result of imbalance between the needs of the digital age that calls for the active use and immediate application of the latest technology in education process and a lack of innovative teaching approaches involving the use of top online tools to teaching literature in 
the digital age. An additional problem is created by the fact that literature teachers are in desperate need of adapting their traditional literature courses covering long literary periods so that they satisfy the needs of their digital-native students who would rather 'click, browse, share and comment' online than provide long essays in pen concerning the works of the most prominent literary figures included into the syllabus. The origin of this problem might lie in the fact that there are numerous studies dealing with modern techniques and approaches to teaching and learning that involve the implementation of online educational tools in language teaching, but unfortunately, few of them deal with their application in literature teaching in particular. This may be the reason why more emphasis has been generally put on teaching linguistics and applied linguistics than teaching literature at universities. $\mathrm{Be}$ as it may, the rise of linguistics and research studies dealing with the application of online tools to language teaching contributed to the popularity of teaching language skills and led to the decline of the importance of literature, and thus its poor inclusion into the curricula and syllabi of colleges and universities.

The aim of this paper is to 'bring life' to literature by exploring, detecting and analyzing the most innovative approaches to teaching literature that include the implementation of online tools in literature courses along with games, the use of audio-video technology, communication and language-based activities. By exploring the creative and modern ways in which literature can be presented to digitalnative students and emphasizing the urgent need of further research when it comes to the application of online tools in literature teaching, we endeavor to directly address the challenges of teaching literature in the $21^{\text {st }}$ century and provide creative suggestions for accelerating the process of transition from traditional literature courses to digitally-based literature courses of the $21^{\text {st }}$ century. The first part of this paper explores online tools that may be applied to teaching literature and addresses the challenges that arise and need to be overcome in teaching literature in the digital age, while the second part of this paper deals with presenting the teaching methods that have already been implemented in teaching Victorian literature to the second-year students of the Faculty of Philology at Sinergija University in Bijeljina during the academic year 2019/2020.

\section{ONLINE TOOLS IN TEACHING LITERATURE}

The rise of information and communication technologies has led to new challenges in different disciplines and an urgent need for the creation, revitalization and adoption of new teaching approaches to meet the expectations of the $21^{\text {st }}$-century students. Teaching literature has proven to be the most resistant to the integration and use of modern technologies, as literature was predominantly associated with deeply spiritual, emotional and mental notions that could hardly be linked with the utilitarian world of technology. In the paper entitled "Teaching English Literature 
in the Digital Era", Škobo and Dragičević-Đerić (2019: 84) have inquired how we can successfully and adequately "identify, explore and interpret the human values lying in the core of any literary work" by applying modern technology if we know that technology is intimately bound with the dehumanization of society. This observation points to the necessity for redefinition of the goals set and methodologies used in teaching literature, in order to harmonize the traditional and conventional approaches with the innovative and creative ones used in the digital age.

Digital citizens are expected to be introduced to multimodality (Kress 2010) and new literacy practices that have utterly changed the existing writing and reading practices as well as the ways literary texts have been produced and received in literature classes. Literature teachers in the digital age constantly struggle to find the approaches that would integrate contents and include the use of ICT in both traditional and virtual classrooms. Many scholars have agreed that Social Networking Sites (SNS) (Facebook, Twitter, Wiki, Instagram or SnapChat, blogs / WordPress. com or blogger.com/), online magazines, films, images, and other similar tools should be included into the literature courses and have stressed the importance of acknowledging the fact that these texts are being woven into both our culture and literary experience (Scholes 2010; Cushman 2011; Johnson 2016; Laflen 2016; Parrott 2016; Parks 2016; Reimer 2016; Rodrigo 2016; Nikolić 2017; Škobo, Đerić-Dragičević 2019).

All these forms of media encourage self-expression on the part of the users and this is known as User Generated Content (Levina, Arriaga 2014). As creating the possibility of self-expression is particularly significant for literature and interpretation of literary texts, the use of these media forms in literature classes is highly desired. However, particular attention should be paid to the proper usage of these media forms. Only the efficient and effective use of new forms of media - video games, graphic novels, interactive hypertexts, language platforms and other digital tools - in teaching literature could inspire students to think critically, work collaboratively and learn more effectively.

\section{THE USE OF NEW FORMS OF MEDIA IN TEACHING LITERATURE}

The use of books in printed format has long ceased to be the only reliable way of approaching literary texts in the digital age. The use of digital narratives or stories has become more convenient and flexible as these online tools link the acquisition and development of reading and literacy competence to digital and media competence, which is a prerequisite in the $21^{\text {st }}$ century. Many researches have pointed out the importance of digital stories when it comes to promoting student critical thinking and language development (Robin 2006, 2016; Benmayor 2008; Ohler 2008; Hartley, McWilliam 2009; Robin, McNeil 2012; Brenner 2014; 
Ibarra-Rius, Ballester-Roca 2019). However, in order to adequately use online educational tools in literature teaching, teachers should be provided with appropriate training practice. Several studies have pointed out that there is a pressing need for the adequate literacy training of the literature teachers/mediators, as they have an important role in creating steady reading habits among the student population and triggering a critical and autonomous interpretation of the literary text (Applegate, Applegate 2004; Nathanson, Pruslow, Levitt 2008; Cremin et al. 2009; Benevides, Peterson 2010; Ibarra-Rius, Ballester-Roca 2019).

Perhaps one of the most interesting and innovative resources available is the use of a book trailer in contemporary literature education. The book trailer is defined as "as a tool to promote books in video format, by using similar techniques to cinematographic trailers, with the peculiarity that it is spread by means of the social networks" (Tabernero, Calva 2016: 55). If used properly, book trailers could be regarded as online educational tools with a great potential in higher education, as they promote literary reading while integrating both audiovisual and multimodal possibilities. As Taylor (2011: 16) has pointed out, the use of book trailers in teching literature could be highly motivational for students since it implies "(an)other way to connect to the texts we were reading and writing in class". Ibarra-Rius and Ballester-Roca (2019: 245) have also pointed out that book trailers could be successfully used in literacy training of future teachers. Namely, they have stressed the importance of bringing book trailers into university classrooms, as they arm future teachers with strategies to promote reading in pre-school and primary education classrooms and encourage "the critical selection of texts and the interpretation and critical production of multimedia messages, in other words, media and digital literacy" (Ibarra-Rius, Ballester-Roca 2019: 246).

Another digital tool that could be used in teaching traditional literary texts is a blog. In their essay on using blogs in literature classes, Giralt and Murray (2019: 278) have endeavoured to describe the pedagogical impact, effectiveness and viability of using blogs to enhance both student learning and peer collaboration. The results of their study have shown that achieving effective collaborative practice amongst students has proven to be the sternest challenge, but also the greatest reward for the teachers in the literature module (Giralt, Murray 2018: 291). According to this study, most students enjoyed the experience but still a few prefer not to engage with the collaborative peer exchanges and feel constrained when asked to do so, while further conflicting viewpoints concerned the use of blogging for academic writing.

The skills the students develop through effective usage of the social media, digital tools and multimodalities can be applied to studying traditional literary texts, in particular, classic literature books written by the most prominent Victorian writers. Many scholars have noted the pressing need for incorporating digital tools into teaching Victorian literature (Crompton 2017; Fleming 2017; Nikolić 2017; Swafford 2017; Škobo, Dragičević-Đerić 2019). In the next section we will present 
a case study based on innovative approaches to teaching, studying and interpreting traditional Victorian texts that encompasses a practical use of forum discussions created via Wix Mobile Application, the benefits of employing a language platform (Actively Learn Platform), the use Facebook with its Timeline feature, as well as the active use of online quizzes and games on Sporcle - World's Largest Trivia Website Quiz - in teaching Victorian literature to the second-year students at the Faculty of Philology in Bijeljina.

\section{ASSIGNMENTS}

\subsection{TASK I - FORUM DISCUSSION VIA WIX MOBILE APPLICATION}

Before the course on Victorian Literature had formally begun in October 2019, a forum or 'comment section' had been set up for discussing the novels that were about to be analyzed during the course in a virtual classroom. Wix Artificial Design Intelligence (ADI) was used for forum creation. The access to the forum entitled Victorian Literature (https://milenanikolic86.wixsite.com/website) or comment section was restricted to students and they were reminded of privacy concerns. When visiting the forum, the students were informed that they could use nicknames rather than their real names and they were advised to provide as little information about themselves as possible for the sake of privacy protection. The students were advised to download the Wix Mobile App, so they could access the forum discussion more easily, without having to open their computers. After installing the Wix mobile app, they needed to sign up for free by using Facebook, Google or email. Having chosen the desired option, the students needed to join the forum by clicking on the link and entering the invite code sent to them via g-mail. The procedure for using the forum discussion board was the same for each novel analyzed during the class. The forum discussion board was used on a regular basis, that is, once or twice a week, after the students had been introduced to the main ideas and themes explored within the literary work. For instance, after introducing students with the main characteristics of the novel The Mill on the Floss by George Eliot and gradually leading students to come to realize the main protagonist's moral dilemmas, a forum discussion board was used for posting the question regarding the novel (i.e. Is Maggie Tulliver a tragic heroine in your opinion? Why / Why not?). The students were asked to comment, like the post, upload a photo/video related to the topic or pose questions to their peers. They were particularly encouraged to share certain parts of the book supporting their opinion. With time the students felt more comfortable with the forum discussion board as they had never used it before in any language/literature classes. They were also free to ask and answer questions related to the literary work analyzed and the teacher frequently challenged the students by assigning the corresponding problem-solving tasks. 


\subsection{TASK II - ACTIVELY LEARN PLATFORM}

Another online tool used during the course on Victorian Literature to enhance traditional reading experience was the Actively learn platform (https://read. activelylearn.com/\#teacher/catalog) - a language platform which makes use of ebooks that are now widely popular in literature classes. This platform proved to be greatly efficient as it extends the learning process that takes part in the traditional classroom beyond the walls of the institution and offers the teacher's constant support to students.

At the beginning of the course, the students were shortly introduced to the platform. The teacher explained the terms of use and the benefits of the platform (free access to e-books, text and videos, asking questions related to the text, commenting and exchanging notes anytime the students find suitable, vocabulary-check online by clicking on the link provided). The students were also informed that the teacher would embed comments, questions and annotations into the e-book's text analyzed during exercise classes on regular basis. In order to access the platform, the students needed to sign up with Google, Office, Clever or email address and join the teacher's class by entering the code sent to them via g-mail.

During the second week of the course, the students were introduced to Charles Dickens and his capital works. In order to motivate and engage students in the discussion, the teacher used a ten-minute-long video on Charles Dickens, available on the Actively Learn platform (https://read.activelylearn.com/\#student/ reader/1984392/notes). Before watching the video, the teacher asked the students to pay attention to what else they could learn about the time period in which Dickens lived. When using the video available on the platform, the teacher was allowed to embed her own comments and questions into the video and/or use those offered by the platform itself. The questions embedded into the video were predominantly in the form of a short answer and multiple choice. In addition to this, the teacher was offered an option to activate "Extra Help" within each question to differentiate and provide additional scaffolds for the struggling students. Since students need different levels of support, the teacher could easily offer assistance to those who need more help. There was an option of giving the explanation after each answer. After choosing the adequate question form and setting the assignments, the teacher sent assignments directly to students by sharing a link with them.

During the third week of the course, the students were assigned tasks related to the excerpts from the novels Oliver Twist and Great Expectations, which were supposed to be read and discussed by students in detail during exercise classes. While the students were given an option to choose which four print books or ebooks (out of seven) included into the syllabus they should read for the oral exam, the teacher required that they should access the platform weekly in order to do the excerpt-assignments designed for exercise classes. During exercise classes, only selected sections from Oliver Twist (Chapter II, 11-14) and Great Expectations 
(Chapter VIII, 47-49) were analyzed. For the purpose of these classes, the teacher added/edited directions for students, added/edited extra help summary, added/ edited the pre-reading question and added a question to end each section of the e-book text-excerpt. For each question text the teacher is offered 'question stems' (i.e. How would you describe...?; Compare and contrast...; What evidence supports...; Can you analyze the impact of...). The teacher can also select a standard from the menu bar regarding the nature of the question (i.e. Main Ideas, Characters \& Plots, Themes, etc.). The question text can be in the form of a short answer, multiple choice or a poll. After choosing the adequate question form and setting the assignments, the teacher sent students directly to assignments by sharing the link with them (https://read.activelylearn.com/\#teacher/reader/grading/1984351/notes).

\subsection{TASK III - FACEBOOK PAGE CREATION}

The third assignment set before the second-year students attending the course of Victorian literature at the Faculty of Philology at Sinergija University included creating a Facebook page of the chosen literary character (or its corresponding film character). The students were allowed to choose the characters from the following novels: Dickens's Oliver Twist and Great Expectations, Thackeray's Vanity Fair, Brontë's Wuthering Heights, Eliot's The Mill on the Floss, Hardy's Tess of the d'Urbervilles and Wilde's The Picture of Dorian Gray. For the purpose of this activity, the students were asked to log in on their Facebook accounts (Page name and category were requested) and fill in all the necessary information concerning their character's life. As the Timeline feature allows an accurate tracking of the plot developments, turning points in the characters' life and their interactions with other characters within the fictional world set in the specific socio-historical context, recreating the identities of the students' characters was neither time-consuming nor a complex task.

This assignment was used instead of oral presentations for earning extra points. The students worked in pairs and groups of 3 during a two-week long period. Each pair/group was asked to choose one literary character from the book that had been already discussed and analyzed, create the character's profile as a page, complete the information section, maintain the page regularly, and 'become Friends' with the fictional characters created by their peers in order to interact on Facebook. In order to demonstrate the effects of the assignment properly, we will briefly focus on the procedure concerning the creation of pages of the main characters of Oscar Wilde's novel The Picture of Dorian Gray: Dorian Gray, a painter Basil Hallward, a notorious instigator Lord Henry Wotton and Sybil Vane, an actress in love with Dorian. In order to make their characters more convincing, the students were asked to watch one of the two film versions based on Wilde's novel: the 1945 American horror-drama film directed by Albert Lewin and the 2009 British fantasy-horror drama directed by Oliver Parker. The students were encouraged to post comments 
and use videos, photos, emoticons and GIFs to support the main ideas expressed by their characters as well as the key events and turning points that took place in their lives. More importantly, they were challenged to get into their characters.

Filling in the information section of a character's profile was quite purposeful, since it assumed the students' engagement with finding the concrete facts and information about the character's life, such as Basic Info, Work and Education, History by Year, Relationship Status, etc. For the purpose of completing the data, the students mostly used Google Search and the Victorian Web site (http://www. victorianweb.org).

After doing their research, the students classified the information they discovered and decided what should be revealed to the public and hidden from it. The deeds and events that the characters (i.e. Dorian Gray) were unwilling to reveal since they damaged their reputation (the deteriorating portrait of Dorian Gray showing his true nature) might be exposed by other characters (i.e. Basil, who finds out the truth about Dorian's changing portrait) by tagging the character in an incriminating photo or posting on his wall (in this concrete case, the narrative would take an unexpected turn that would lead to surprising versions of the novel's ending).

The students as creators of the character's page are given the opportunity to decide what their character should 'Like' or add to his or her list of 'Favorites', including books, people they admire, music, events, etc. This Facebook feature proved to be quite useful as it encouraged the students to go deeper into the analysis of the original text and search for information supporting their decisions what to like on the social network (i.e. Dorian Gray liked the pages about fashion, style and art and all newfangled magazines; he was also 'interested' in the events such as 'dinner parties', 'cocktail parties', 'theatre going', or the events that suggested 'a life of debauchery'). By considering what Dorian Gray would like, who he would interact with, what events he would choose to visit, the students are subconsciously dragged into the process of constructing the character's identity in the context of social media behaviors. Also, since some of the options that Facebook offers are unavailable to character pages, the students had to find the way how to express their disliking or antipathy towards certain characters (i.e. Lord Henry's disliking of Sybil Vane was expressed by Lord Henry's observations concerning her poor acting). In addition to this, the students made use of the 'status update' option on Facebook, where they were able to engage in conversations with multiple characters chosen from the book, share their views of key events or specific scenes from the text and trigger discussions in real time.

As the narrative unfolded, the students updated their status and engaged themselves in the process of character development. They searched for interesting conversations in the original text and shared their character's views on many issues. For instance, Lord Henry's derogatory view of women is expressed by posting the following conversation between Lord Henry and Dorian: "My dear boy, no woman 
is a genius. Women are a decorative sex. They never have anything to say, but they say it charmingly. Women represent the triumph of matter over mind, just as men represent the triumph of mind over morals" (Wilde 2001: 40). Simultaneously, by uploading a photo or video, another feature offered by Facebook, the students demonstrated their creativity in a variety of ways. While some students opted for creating the characters following the information given in the text itself, others chose to do the 'remake', that is, to transform their $19^{\text {th }}$-century characters into

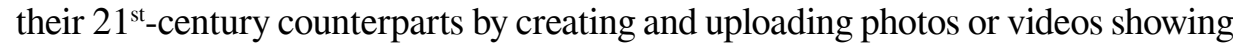
how they thought their characters would dress, talk and behave if they existed in the digital era.

\subsection{TASK IV - INTEGRATED SKILLS}

During the course of English Literature II (Victorian literature), along with the application of online tools and social media into literature classes, the teacher has also used online games and quizzes, communicative language teaching activities and modern language-based activities that employ the four main language skills, activate the students' prior knowledge and engage students in meaningful communication. The students were given a textbook with the activities selected, designed, and adapted by the teacher following the excerpts from the Victorian novels analyzed and discussed during the semester. The textbook was particularly designed for exercise classes. It has been suggested that the students should do the activities from the textbook for homework. Due to the limited length of this paper, we will present a few activities related to Dickens's novel Oliver Twist. The excerpt from Oliver Twist that deals with the part in the novel where Oliver is chosen to 'ask for more' gruel (Chapter II, 11-14) is followed with reading comprehension activities (part I), a vocabulary section (part II), and the section designed to trigger the students' critical thinking and prepare them for the oral exam (part III), consisting of discussion questions, the themes for essays and the ideas suggested for further exploitation of the texts.

Reading comprehension consists of answering short questions related to the book excerpt in the form of a quiz (multiple choice questions), watching the corresponding excerpt from the 2005 Roman Polanski's film Oliver Twist on YouTube, putting the events from the film in the chronological order and matching characters with their statements.

The vocabulary section consists of several parts. Firstly, the students were asked to find the meanings to the underlined words in the text by guessing their meaning from the context or using e-dictionaries on their mobile phones. Then the students were asked to provide their synonyms/antonyms, and check their adjective/adverb/noun/verb form. The second part of the vocabulary section consists of theme-based activities: since the main themes of Oliver Twist are money, poverty 
and crime, the students were provided with the activities based on vocabulary building related to crime and criminality and being rich/poor. The students were given some phrases, expressions, collocations and idioms indicating the qualities of being rich/poor (i.e. impoverished, well-heeled, as poor as the church mouse, rolling in it, a tycoon, on the rocks, needy, a fat cat, well-off, hard-up) and were asked to find the adequate translation of the words in their mother tongue. Word formation activity based on the e-text on Dickens and child labour was also used. The activities based on Crime vocabulary included a 'multiple choice question-quiz', matching the type of offence with its definition, providing the name of the person committing a crime and the verbs associated with the crime. The theme-based activities are predominantly adapted from the vocabulary books the students were asked to refer to during the courses of Contemporary English Language III and Contemporary English Language IV (English Vocabulary in Use, English Vocabulary in Use (Advanced), Focus on Advanced English, Advanced Language Practice, etc.).

The games used in teaching Victorian Literature were predominantly found on Sporcle - World's Largest Trivia Website Quiz (https://www.sporcle.com/). The students were asked to join Sporcle for free by signing up with Facebook, Google or email. By typing the information in the Search field (i.e. Oliver Twist), a list of 32 quizzes in total is provided (i.e. Clickable Oliver Twist Characters, Who Said It? Oliver Twist, Oliver Twist Movie Years, Oliver Twist 'Start to Finish', The Dickens of an Anagram! Oliver Twist, etc.). Each quiz has got a score and timer to limit the time needed for answers. The use of this website turned out to be particularly interesting as it provided an option for multiple player-games. The students with the accounts set to accept challenges could play the game with each other. In order to do that, they should go to the quiz they want to play and click on the challenge button (just above the quiz) and select the friend. The website also offers an option of creating a new quiz. There are several quiz types to select: classic, clickable, grid, map, multiple choice, picture box, picture click or slideshow. After choosing the quiz type, the creator should name the quiz, describe it in few words, set the quiz timer, select the answer type and category (i.e. literature). This option proved to be quite attractive to students, as many of them wanted to create their own quiz and challenge their peers.

\section{CONCLUSION}

The results of the study conducted during the three-month course on Victorian literature have shown that the use of forum discussion board created via Wix Mobile App proved to be quite efficient and time-saving as it made the teacher's efforts to help students get the gist of the book less intense. The students liked the application as it resembled Facebook and were eager to read comments, post regularly and open discussions inspired by the moral dilemmas of the main characters, 
interesting facts about Victorian authors and social problems of the $19^{\text {th }}$-century Britain.

One of the greatest advantages of using the Actively Learn platform is the option provided to the teachers to send their own notes through the internet directly to the students' copies of the e-books. Simultaneously, the students are allowed to write their own notes, ask questions or comment on the notes that other students have written, thus creating a strong bond regarding the student-student or studentteacher relationship. The platform provided the teacher with materials such as a video on Charles Dickens and various Actively Learn assignments regarding the greatest Dickens's novels, as well as the possibility of incorporating (adding, adapting, creating) the teacher's own materials, assignments and instructions.

By translating the literary work into the language of social media familiar to them (Facebook), the students are invited and encouraged to discuss unfamiliar and often complex literary perspectives and add new meanings to the literary works interpreted from multiple perspectives. Creating a Facebook page of the chosen literary character has deepened the students' understanding of the literary work in general, clarified complex interrelations among different characters and motivated students to look for extra information about the character by turning to various online sources.

A lack of the research studies dealing with the implementation of online educational tools in teaching literature has led to the decline of the students' interest in literature, and thus its poor inclusion into the curricula and syllabi of colleges and universities. Broadening the scope of study related to the application of the most recent technology, social media and digital tools in language teaching to that of teaching literature in particular, along with providing the adequate training for the future teachers regarding the proper usage of the new forms of social media and online tools would significantly improve the status of literature in the $21^{\text {st }}$ century. In addition to this, the two major challenges of teaching literature in the digital age have been the lack of standardized exams online (the adequate online testing), as well as the imbalance between traditional teaching practices and the expectations of digital-native students who are used to multitasking, which has resulted in a pressing need for redefining the goals set and methodologies used in teaching literature.

Creative suggestions for accelerating the process of transition from traditionally-based literature classes to the digitally-based ones provided in this paper encompass the efficient and effective use of Social Networking Sites along with online tools, games and communicative language activities. It has been concluded that the proper use of new media forms in teaching literature could trigger students' motivation, inspire critical thinking, and ensure work in a collaborative environment. 


\section{REFERENCES}

Applegate, Applegate (2004): A. J. Applegate, M. D. Applegate, The Peter Effect: Reading habits and attitudes of preservice teachers, The Reading Teacher, 57, 554-556.

Benevides, Peterson (2010): T. Benevides, S. S. Peterson, Literacy attitudes, habits and achievements of future teachers, Journal of Education for Teaching, 36(3), 291-302.

Benmayor (2008): R. Benmayor, Digital storytelling as a signature pedagogy for the new humanities, Arts and Humanities in Higher Education, 7(2), 188-204.

Brenner (2014): K. Brenner, Digital stories: A 21st century communication tool for the English language classroom, English Teaching Forum, 52(1), 22-29.

Cremin, Mottram, Collins, Powell, Safford (2009): T. Cremin, M. Mottram, F. Collins, S. Powell, K. Safford, Teachers as readers: Building communities of readers, Literacy, 43(1), 1-11.

Crompton (2017): C. Crompton, Teaching About and Through Computing: Victorian Record Keeping, Data Management, and the class Edition, In: J. Cadwallader, L. W. Mazzeno (Eds.), Teaching Victorian Literature in the Twenty-First Century: A Guide to Pedagogy, USA: Palgrave MacMillan, 211-226.

Cushman (2011): E. Cushman, New Media Scholarship and Teaching: Challenging the Hierarchy of Signs, Pedagogy: Critical Approaches to Teaching Literature Language Composition and Culture, 11(1), 63-79.

Dickens (2000): C. Dickens, Great Expectations, Ware [England]: Wordsworth Editions.

Dickens (2000): C. Dickens, Oliver Twist, Ware [England]: Wordsworth Editions.

Fleming (2017): P. C. Fleming, The Office is One Thing, and Private Life is Another, In: J. Cadwallader, L. W. Mazzeno (Eds.), Teaching Victorian Literature in the TwentyFirst Century: A Guide to Pedagogy, USA: Palgrave MacMillan, 197-210.

Giralt, Murray (2019): M. Giralt, L. Murray, Reflexion, Analysis and Language Practice: From Individual Critical Thinking to Collaborative Learning Using Blogs in a Literature Class, In: M. L. Carrió-Pastor (Ed.), Teaching Language and Teaching Literature in Virtual Environments, Singapore: Springer, 277-293.

Hartley, McWilliam (2009): J. Hartley, K. McWilliam, Story circle: Digital storytelling around the world, London: Wiley-Blackwell.

Johnson (2016): T. Johnson, 'Hath he not twit?': Teaching Shakespeare through Twitter, In: T. Hetland (Ed.), Teaching Literature with Digital Technology, Boston / New York: Bedford / St. Martin's, 99-109.

Kress (2010): G. Kress, Multimodality: A social semiotic approach to communication, London / New York: Routledge.

Laflen (2016): A. Laflen, Wiki Critical Editions: Collaborative Learning in the Literature Classroom, In: T. Hetland (Ed.), Teaching Literature with Digital Technology, Boston / New York: Bedford / St. Martin's, 34-49.

Levina, Arriaga (2014): N. Levina, M. Arriaga, Distinction and status production on user-generated content platforms: Using Bourdieu's theory of cultural production to understand social dynamics in online fields, Information Systems Research, 25(3), 468-88.

Ibarra-Rius, Ballester-Roca (2019): N. Ibarra-Rius, J. Ballester-Roca, Digital Storytelling in Teacher Training: Development of Basic Competences, Creativity and Multimodal Literacy Through Book Trailers, In: M. L. Carrió-Pastor (Ed.), Teaching Language and Teaching Literature in Virtual Environments, Singapore: Springer, 241-254. 
Nathanson, Pruslow, Levitt (2008): S. Nathanson, J. Pruslow, R. Levitt, The reading habits and literacy attitudes of inservice and prospective teachers: Results of a questionnaire survey, Journal of Teacher Education, 59(4), 313-321.

Nikolić (2017): M. Nikolić, The use of audio and video recordings in English language teaching, XVIII International Scientific Conference - Sinergija 2017, Sinergija University, Bijeljina, Republic of Srpska, 120-124.

Ohler (2018): J. Ohler, Digital storytelling in the classroom: New media pathways to literacy, learning and creativity, Thousand Oaks: Corwin Press.

Parrott (2016): J. Parrott, Writing on the Wall: Using Facebook's Timeline for Literary Analysis, In: T. Hetland (Ed.), Teaching Literature with Digital Technology, Boston / New York: Bedford / St. Martin's, 21-35.

Parks (2016): J. Parks, A Digital Approach to Teaching Postmodern Literature, In: T. Hetland (Ed.), Teaching Literature with Digital Technology, Boston / New York: Bedford / St. Martin's, 110-121.

Reimer (2016): E. Reimer, More Perfect Unions: Literary Studies, Blogging, and the Multigenre Essay, In: T. Hetland (Ed.), Teaching Literature with Digital Technology, Boston / New York: Bedford / St. Martin's, 69-83.

Robin (2006): B. Robin, The educational uses of digital storytelling, In: C. Crawford, R. Carlsen, K. McFerrin, J. Price, R. Weber \& D. Willis (Eds.), Proceedings of society for information technology and teacher education international conference, Chesapeake, VA: AACE, 709-716.

Robin, McNeil (2012): B. Robin, S. McNeil, What educators should know about teaching digital storytelling, Digital Education Review, 22, 37-51.

Robin (2016): B. Robin, The power of digital storytelling to support teaching and learning, Digital Education Review, 30(30), 17-29.

Rodrigo (2016): R. Rodrigo, Writing a Wiki Resource Guide for a Literature Survey Course, In: T. Hetland (Ed.), Teaching Literature with Digital Technology, Boston / New York: Bedford / St. Martin's, 50-68.

Scholes (2010): R. Scholes, The English Curriculum After the Fall, Pedagogy: Critical Approaches to Teaching Literature Language Composition and Culture, 10(1), 229-240.

Swafford (2017): J. Swafford, Virtually London: Literature and Laptops, In: J. Cadwallader, L. W. Mazzeno (Eds.), Teaching Victorian Literature in the Twenty-First Century: A Guide to Pedagogy, USA: Palgrave MacMillan, 227-238.

Tabarnero, Calvo (2016): R. Tabarnero, V. Calvo, Book-trailers as tools to promote reading in the framework of the Web 2.0, New Review of Children's Literature and Librarianship, 22(1), 53-69.

Taylor (2011): J. Taylor, Selling literacy: A young teacher's tale of getting (and keeping) her students excited about text, Language Arts Journal of Michigan, 27(1), 16-19.

Wilde (2001): O. Wilde, The Picture of Dorian Gray, Ware, Hertfordshire: Wordsworth Editions Limited.

Škobo, Đerić-Dragičević (2019): M. Škobo, B. Đerić-Dragičević, Teaching English Literature in the Digital Era, XX International Scientific Conference - Sinergija 2019, Sinergija University, Bijeljina, Republic of Srpska, 84-89. 


\section{Милена 3. Шкобо}

Универзитет Синергија

Филолошки факултет

Катедра за енглески језик и књижевност

\section{ИНОВАТИВНИ ПРИСТУПИ У ПОДУЧАВАЮУ (ВИКТОРИЈАНСКЕ) КЮИЖЕВНОСТИ У ДИГИТАЛНОМ ДОБУ}

Резиме: Циљ овог рада јесте да истражи најновије приступе у подучавању књижевности викторијанског доба на терцијарном нивоу образовања. Рад се бави изазовима у подучавању књижевности у дигиталном добу и описује неколико неконвеционалних приступа у изучавању, подучавању и тумачењу традиционалних књижевних текстова, те техника и стратегија које су примењиване током курса у зимском семестру академске 2019/2020. године на Филолошком факултету Универзитета Синергија у Бијељини у Републици Српској, а који обухвата књижевност викторијанског доба у оквиру предмета Енглеска књижевност II. Методологија рада примењивана код студената друге године на предмету Енглеска књижевност II обухватала је отварање форума за дискусију помоћу Викс мобилне апликације (Wix Mobile Application), коришћење Actively Learn језичке платформе, отварање Фејсбук странице одабраном књижевном лику и израду онлајн игрица и квизова уз помоћ највећег светског веб-сајта за квизове који носи назив Сӣopкл (Sporcle). У циљу спровођења наставе ове врсте коришћене су онлајн алатке и друштвене мреже, упоредо са онлајн игрицама и квизовима, као и активностима и стратегијама које помажу у развоју говорно-језичких вештина, активирају пасивно знање и искуство и подстичу студенте да воде смислене разговоре, а који произлазе из њиховог разумевања књижевних текстова, те разумевања паралела које се могу подвући између 19. и 21. века, посматрано из перспективе дигиталних урођеника. Рад отвара нова питања која се тичу употребе савремене технологије и најновијих онлајн образовних алатки у подучавању књижевности уопште и указује на нужност спровођења даљег истраживања када је реч о подучавању књижевности у дигиталном добу.

Кључне речи: дигитално доба, подучавање књижевности, неконвенционални приступи, онлајн-алатке. 